\title{
COMPARATIVE GEOCHEMISTRY OF KIMBERLITES FROM THE LAC DE GRAS FIELD, NWT - AN INTEGRATED ISOTOPIC AND ELEMENTAL STUDY
}

\author{
DP Dowall ${ }^{\mathbf{1}}$, DG Pearson ${ }^{1}$, GM Nowell ${ }^{1}$, BA Kjarsgaard ${ }^{2}$, J Armstrong ${ }^{3}$ and MSA Horstwood ${ }^{\mathbf{4}}$ \\ ${ }^{I}$ Arthur Holmes Isotope Geology Laboratory, Durham University, UK; ${ }^{2}$ Geological Survey of Canada, Ottawa, Canada; \\ ${ }^{3}$ DIAND, Yellowknife, Canada; ${ }^{4}$ NERC Isotope Geoscience Laboratory, Keyworth, UK
}

\section{INTRODUCTION}

Recent studies of the Hf-Nd-Sr isotopic characteristics of kimberlites and lamproites from southern Africa (Nowell et al. 1999a; 1999b) have demonstrated that these deep-seated magmas commonly plot below the MORB-OIB 'mantle array' in Hf-Nd isotopic space. This type of signature - termed negative delta epsilon Hf (Johnson and Beard, 1993) - suggests the incorporation of a unradiogenic, enriched isotopic component at some point during formation and/or evolution of the parental magma. Potential sources proposed for such a component, which has not as yet been observed in other mantle-derived magmatic rocks, include:

1. The sub-continental lithospheric mantle, through which deep-seated magmas must pass en route to the surface (Nowell et al., 1999a; Griffin et al., 2000).

2. A boundary layer at depth within the mantle (such as the $670 \mathrm{~km}$ discontinuity or core-mantle boundary), isolated from the homogenising effects of convective processes and sampled only by magmas of extremely deep origin (Nowell et al., 1999a; 1999b).

The existence of a negative delta epsilon Hf reservoir within the mantle may also explain the proposed displacement of Bulk Silicate Earth (BSE) beneath the mantle array (Blichert-Toft and Albarède, 1997) in terms of a Hf-Nd isotopic mass balance. The isotopic signatures observed in kimberlites and lamproites appear to be the strongest manifestation of such a reservoir (Nowell et al., 1998). A recent study of Hf isotopic variations in an Archean carbonatite (Bizzarro et al., 2002) also appears to support these observations, albeit based on analyses of baddeleyite grains for which large age corrections are required; further work is therefore necessary to substantiate this result.

For this study high precision $\mathrm{Hf}, \mathrm{Nd}$ and $\mathrm{Sr}$ isotope data coupled with major and trace element analyses have been acquired for 98 samples of kimberlite from the Slave province, including 86 samples from intrusions within the Lac de Gras kimberlite field, making this the best characterised kimberlite province in the world in terms of isotope and trace element geochemistry. 70 of the Lac de Gras samples are hypabyssal facies material. A subset of 14 samples drawn from a single hypabyssal facies kimberlite locality within the Lac de Gras field enables the extent of intra-kimberlite major/trace element and isotopic variation to be investigated in detail. This well-constrained subset can then be used as a reference point for studying inter-kimberlite variations both within and beyond the Lac de Gras region and Slave craton.

\section{SAMPLES}

The kimberlites investigated here have been drawn from a range of spatial and temporal groupings within the Slave craton. The majority of samples are from the Cretaceous-Eocene Lac de Gras field (central Slave), while others are from the Jurassic Contwoyto Lake field (northern Slave), Cambrian and Ordovician kimberlite localities (southern Slave) and the Cretaceous Somerset Island field (Churchill province). Petrography and Re-Os dating of xenoliths from beneath these regions indicates the presence of Archean lithospheric mantle below the crust (Irvine et al., in press; Carbno and Canil, 2002). Petrographic examination of the Slave kimberlites studied here and previously (Price, 1998; Berg and Carlson, 1998) indicates that they are mineralogically similar to, although generally fresher than, South African Group I kimberlites. Fresh monticellite is typically preserved in the groundmass of the samples from the Lac de Gras area, and many of these samples are best described as phlogopite-bearing monticellite kimberlites.

\section{RESULTS}

\section{MAJOR AND TRACE ELEMENTS}

Major and trace element data tend to support the petrographic observation that the majority of the Slave kimberlites are minimally altered and have experienced little crustal contamination. This is in particular the 
case for the hypabyssal samples, which comprise the majority of our sample suite. Values of the contamination index (C.I.) calculated using the method of Clement (1982) for these samples typically range between 0.8 and 1.3. However, some caution is required in applying the C.I. to the Slave kimberlites, as some samples have low C.I. but anomalously high $\mathrm{Al}_{2} \mathrm{O}_{3}$ contents, which is indicative of assimilation of crustal material. The C.I. is also sensitive to the effects of fractionation of olivine and phlogopite, as well as differential entrainment of peridotitic olivine from the lithospheric mantle.

Compatible and incompatible element abundances of Slave kimberlites are broadly consistent with those of Kaapvaal Group I and transitional samples, although the Slave samples are notably enriched in some elements, e.g. Ba, and depleted in others, e.g. Y, Zr, Hf. Averages of chondrite-normalised REE data support the general similarities between Kaapvaal and Slave samples (i.e. enrichment in light REEs, depletion in heavy REEs), although the magnitude of the mid- to heavy-REE depletion is significantly greater in the Slave samples. This could be explained by their lower levels of crustal contamination.

Discrimination diagrams based on the differential behaviour of large ion lithophile elements (LILE, e.g. Ba) and high field strength elements (HFSE, e.g. La) during magmatic processes have been used to distinguish Kaapvaal Group I and II kimberlites (Le Roex, 1986). On a plot of $\mathrm{La} / \mathrm{Nb}$ vs. $\mathrm{Ba} / \mathrm{Nb}$ the Slave and Churchill samples demonstrate a significant degree of overlap with Kaapvaal Group I samples, but with some tendency towards the higher $\mathrm{Ba} / \mathrm{Nb}$ ratios of Kaapvaal Group II and transitional samples. In summary, despite petrographic similarities between Slave and Kaapvaal Group I kimberlites, there are some differences in terms of trace element abundance.

\section{HF-ND-SR ISOTOPES}

In $\mathrm{Nd}-\mathrm{Sr}$ isotopic space the freshest Slave samples form a well-defined envelope with a range of epsilon $\mathrm{Sr}$ values $(0$ to +20 epsilon units $)$ that is offset from that typical of Kaapvaal Group I kimberlites (-15 to 0 epsilon units). A subset of the least contaminated hypabyssal samples from Lac de Gras have epsilon $\mathrm{Sr}$ from 0 to +10 , indicating that there is a correlation between amount of contamination and magnitude of the epsilon Sr signature. Most of the samples which show deviations towards high positive epsilon $\mathrm{Sr}$ have low elemental $\mathrm{Sr}$ abundances, such that the effect of incorporating enriched crustal signatures is likely to be more pronounced.

Although the range of epsilon $\mathrm{Nd}$ values ( 0 to -5 units) that encompasses most of the central Slave samples place them directly between the South African Group I ( 0 to +5 units) and Group II ( -5 to -15 units) fields, analyses of samples from the Jericho kimberlite in the more northerly Contwoyto Lake field (northern Slave) and those from Somerset Island have an epsilon $\mathrm{Nd}$ range of between 0 and +3 units, placing them directly within the Kaapvaal Group I field. Four of the six Cambrian samples from the more southerly part of the Slave craton also have epsilon $\mathrm{Nd}$ in the range of 0 to +5 units and plot within this same field. These deviations from the $\mathrm{Nd}$ isotopic signature of central Slave kimberlites could reflect isotopic heterogeneity either between kimberlites derived from different magmatic cycles through time, or between different lithospheric domains being sampled by the intrusions (Grütter et al., 1999; Grütter, 2003).

The 'transitional' epsilon $\mathrm{Nd}$ signature (0 to -5 units) exhibited by the Lac de Gras samples has been observed in several other cratonic regions around the world. Nine $\mathrm{Nd}$ isotopic analyses of Finnish kimberlites from the Karelia craton (O'Brien and Tyni, 1999), define a range of epsilon $\mathrm{Nd}$ from -2.4 to +0.8 units, although only two samples have positive values. Two kimberlites from the São Francisco craton of Brazil (Bizzi et al., 1994) also have epsilon $\mathrm{Nd}$ signatures of -5 to -6 units. Five samples from the Zolotitsa field near Arkhangelsk (Mahotkin et al., 2000) range between epsilon $\mathrm{Nd}$ of -2.4 and -3.6 . Four samples from the Mengyin and Fuxian provinces of China (Tompkins et al., 1999) have epsilon $\mathrm{Nd}$ of -0.2 to -2.5 , with one other sample having a value of +0.7 . All of these samples plot at the very margins of, or well outside, the field defined by southern African Group I kimberlites.

Our new Hf-Nd isotope data show that the Slave province kimberlites overlap almost the entire range of Hf isotopic compositions of South African Group I and II kimberlites. As such, from a $\mathrm{Hf}$ isotope perspective, the source region for Slave kimberlites (which have archetypal 'Group I' petrographic characteristics) cannot be distinguished from those of Group II. The position of the Slave province kimberlites on the Hf-Nd isotope diagram defines a continuum between South African Group I and Group II kimberlites. Hence, in terms of both $\mathrm{Nd}$ and $\mathrm{Hf}$ isotopes, it is very difficult to make a strong case for a separate, olivine-free source 
for Group II kimberlites compared to Group I kimberlites, as suggested by Mitchell (1995).

In Hf-Nd isotopic space the Lac de Gras samples form a coherent array with an orientation that is highly oblique to the mantle array. The majority of samples plot within the range of -10 to +5 delta epsilon Hf units. The samples with the most positive delta epsilon Hf signatures are known from petrographic examination to be exceptionally olivine-rich, resulting from entrainment of large quantities of peridotitic material during passage of the kimberlite through the sub-continental lithospheric mantle. This is consistent with recent Hf-Nd isotopic data on lithospheric mantle xenoliths (Schmidberger et al., 2002; Simon et al., this volume), which plot above the Hf-Nd mantle array.

\section{DISCUSSION}

Our extensive new elemental and isotopic database for kimberlites from the Slave craton allows meaningful comparisons to be made with other kimberlite provinces around the world and allows us to constrain some of the multitude of petrogenetic models put forward to explain the genesis of the different varieties of kimberlite.

There are clear, general petrographic and geochemical similarities between Slave and South African Group I kimberlites. However, there are also definite distinctions - particularly in terms of isotopic characteristics - between these groups. In comparison to South African Group I kimberlites the central Slave samples have lower, negative epsilon $\mathrm{Nd}$ and higher, positive epsilon $\mathrm{Sr}$ values, more comparable to Kaapvaal 'transitional' kimberlite signatures. These isotopic signatures have also been found in kimberlites from Finland (O’Brien and Tyni, 1999), Brazil (Bizzi et al., 1994), the vicinity of Arkhangelsk in Russia (Mahotkin et al., 2000) and China (Tompkins et al., 1999). The prevalence of these 'transitional' isotopic characteristics amongst the Slave kimberlites establishes this signature as a very common one that dominates in certain provinces.

A minority of samples within the Slave province, predominantly from the northern and southern regions (e.g. Jericho, Snap Lake) together with samples from the Churchill province have isotopic signatures that are much more characteristic of South African Group I kimberlites. This could be interpreted as evidence of isotopic heterogeneity between the central and marginal portions of the Slave craton. In addition, the sample from Nicholas Bay and sample HL12 from Hardy Lake are the two most easterly samples analysed from the Lac de Gras area and show some of the lowest combined epsilon $\mathrm{Hf}$ and epsilon $\mathrm{Nd}$ values of all the fresh, uncontaminated samples from the central Slave. This isotopic characteristic may be in part related to these kimberlites being emplaced through the juvenile Neoarchean Hackett River Arc terrane, which lies to the east of the Mesoarchean central Slave Basement Complex. In the Kaapvaal craton too, the most negative delta epsilon $\mathrm{Hf}$ signatures are from transitional kimberlites located towards the edge of, or off- craton.

Alternatively, since the more northerly and southerly situated kimberlites were erupted at different times compared with those of the central Slave the apparent change in source composition may be a temporal one that is dominated by isotopic variation within a heterogeneous asthenospheric reservoir. This viewpoint is supported by the observation that the Hf$\mathrm{Nd}$ isotopic variation between these geographically disparate areas is sub-parallel to the mantle $\mathrm{Nd}-\mathrm{Hf}$ array, which is defined by OIB compositions. In contrast, variation in lithospheric isotopic composition extends over a large range of epsilon $\mathrm{Hf}$, such that significant deviations above and below the mantle array should be expected if lithospheric sources were the dominant cause of the observed Hf-Nd isotope variability in these rocks. In support of this interpretation, initial Os isotope studies of the Slave kimberlites (Pearson et al., this volume), find that Os isotope signatures can be explained by magmas with asthenopheric (OIB-like) isotopic compositions.

A small subset of 14 samples from the central Slave have very negative delta-epsilon $\mathrm{Hf}$ isotopic signatures (lower than -6) that are similar to values observed for Kaapvaal 'transitional' kimberlites, consequently plotting below the OIB envelope of the $\mathrm{Hf}-\mathrm{Nd}$ mantle array. This isotopic signature has now been identified in kimberlites from three different continental regions (Southern Africa, North America and Asia).

In the absence of more data from material that can reasonably be expected to have avoided interaction with sub-continental lithospheric mantle (e.g. members of the Cr-poor megacryst suite) it is still difficult to provide definitive evidence for the source bcation of these unusual delta epsilon Hf signatures. The apparent global extent of the signature is supportive of a model involving kimberlite magma genesis from a laterally extensive ultra-deep reservoir, which is sufficiently isolated from normal mantle convective processes to 
preserve exotic isotopic components. Alternatively, the negative delta epsilon Hf may be derived from the inevitable (though difficult to quantify) interaction of the kimberlite magma with the sub-continental lithosphere or crust. Available data for lithospheric material (Schmidberger et al., 2002; Simon et al., this volume; Nowell et al., in press) shows that peridotitic SCLM actually plots well above the Hf-Nd mantle array, making this model difficult to envisage as a mixing end-member that could consistently produce negative deviations in kimberlites from the mantle array. Pyroxenitic lithospheric components (Nowell et al., in press) can have enriched $\mathrm{Nd}$ and $\mathrm{Hf}$ isotope systematics and can lie either above or below the mantle array. Incorporation of a pyroxenitic and/or eclogitic endmember into the kimberlite source might be expected to lead to considerably greater $\mathrm{Hf}-\mathrm{Nd}$ isotopic diversity than actually observed. Nowell et al. (in press) have argued on the basis of combined megacryst and kimberlite Hf-Nd systematics in South African kimberlites that the negative delta epsilon Hf component originates from a sub-lithospheric component that could be ancient, subducted EMORB, that contributes a fraction towards the parental kimberlite melt. A similar explanation can be advanced for the Slave kimberlites. We have not quantified the potential presence of this component in detail, but it is clear from the relatively small displacement of kimberlites below the $\mathrm{Nd}$-Hf mantle array, together with their chondritic to moderately radiogenic Os isotopic compositions (Pearson et al., this volume), that kimberlites cannot simply be the melting products of subducted oceanic crustal material as suggested by some experimental studies (e.g. Edgar and Charbonneau, 1993).

Our new Slave province isotopic data also have a direct bearing on the relationship between South African Group I and Group I kimberlites. The continuum of Nd-Hf (this study) and Os isotopic compositions (Pearson et al., this volume) now observed across the kimberlite spectrum from Group I to Group II is not supportive of a completely different source for Group II kimberlites. A model where all kimberlites originate beneath the lithosphere and hybridise to varying amounts with different metasomatic components in the lithosphere seems to us the simplest explanation of the available data.

The 'provinciality' of isotopic signature, particularly as observed in terms of epsilon $\mathrm{Nd}$, is strongly expressed when making comparisons between kimberlites from the Slave province and other cratonic areas around the world. The few samples analysed from the Churchill,
Superior and Siberian provinces as part of this study consistently display positive values of epsilon $\mathrm{Nd}$, similar to Group I kimberlites from southern Africa, whereas analyses of kimberlites from the Karelia (O'Brien and Tyni, 1999), São Francisco (Bizzi et al., 1994), Kola (Mahotkin et al., 2000), and Sino-Korean (Tompkins et al., 1999) cratons indicate more affinity with the negative epsilon $\mathrm{Nd}$ values of the central Slave province. We note above that this difference in isotopic composition is essentially sub-parallel to the mantle $\mathrm{Nd}-\mathrm{Hf}$ isotope array and could represent heterogeneity in convecting mantle source regions. This is supported by Os isotope work. We further note that the so-called 'transitional' isotopic compositions are actually dominant in some provinces. In the Slave province, 'transitional' isotopic characteristics occur in kimberlites that are petrographically most akin to South African Group I kimberlites. Hence, we need to reevaluate the appropriateness of the Group I/II terminology, as originally defined by Smith (1983) on an isotopic basis, from a Hf-Nd isotope point of view and within the context of South African Group I and II kimberlites representing 'end-member' compositions.

\section{ACKNOWLEDGEMENTS}

All sample material for this study was kindly supplied by the following organisations: BHP Billiton, Kennecott Exploration, De Beers and Tahera Resources.

\section{REFERENCES}

Berg, G.W., Carlson, J.A., 1998. The Leslie kimberlite pipe of Lac de Gras, Northwest Territories, Canada: evidence for near surface hypabyssal emplacement. Ext. Abstr. $7^{\text {th }}$ Int. Kimberlite Conf., Cape Town, South Africa, pp. 81-83.

Bizzarro, M., Simonetti, A., Stevenson, R.K., David, J., 2002. Hf isotope evidence for a hidden mantle reservoir. Geology, 30, 771-774.

Bizzi, L.A., Smith, C.B., de Wit, M.J., Armstrong, R.A., Meyer, H.O.A. 1994. Mesozoic kimberlites and related alkalic rocks in the southwestern São Francisco craton, Brazil: a case for local mantle reservoirs and their interaction. Proc. $5^{\text {th }}$ Int. Kimberlite Conf., Vol. 1, CPRM, Rio de Janeiro, Brazil, pp. 158-171.

Blichert-Toft, J., Albarède, F., 1997. The Lu-Hf isotope geochemistry of chondrites and the evolution of 
the crust-mantle system. Earth Planet. Sci. Lett., 148, 243-258.

Carbno, G.M., Canil, D., 2002. Mantle structure beneath the SW Slave craton, Canada; constraints from garnet geochemistry in the Drybones Bay kimberlite. J. Petrol., 43, 129-142.

Clement, C.R., 1982. A comparative geological study of some major kimberlite pipes in the Northern Cape and Orange Free State. Ph.D. Thesis, Univ. Cape Town, Cape Town, South Africa.

Edgar, A.D., Charbonneau, H.E., 1993. Melting experiments on a $\mathrm{SiO}_{2}$-poor, $\mathrm{CaO}$-rich aphanitic kimberlite from 5-10Gpa and their bearing on sources of kimberlite magmas. Am. Mineral., 78, 132-142.

Griffin, W.L., Pearson, N.J., Belousova, S.E., Jackson, S.E., van Achterburgh, E., O'Reilly, S.Y., Shee, S.R., 2000. The Hf isotope composition of cratonic mantle: LAM-MC-ICPMS analysis of zircon megacrysts in kimberlites. Geochim. Cosmochim. Acta., 64, $133-147$.

Grütter, H.S., Apter, D.B., Kong, J., 1999. Crust-mantle coupling: evidence from mantle-derived xenocrystic garnets. Proc. $7^{\text {th }}$ Int. Kimberlite Conf., Vol. 1, Red Roof Design, Cape Town, South Africa, pp. 307-313.

Grütter, H.S., 2003. MDRU/UBC Short Course No. 37. Vancouver, January 25-56.

Irvine, G.J., Pearson, D.G., Carlson, R.W., Kjarsgaard, B.A., Dreibus, G., in press. Evolution of the lithopsheric mantle beneath northern Canada: a Re-Os isotope and PGE study of kimberlitederived peridotite xenoliths from Somerset Island and a comparison to the Slave and Kaapvaal cratons. Lithos.

Johnson, C.M., Beard, B.L., 1993. Evidence from Hf isotopes for ancient sub-oceanic mantle beneath the Rio Grande Rift. Nature, 362, 441-444.

Le Roex, A.P., 1986. Geochemical correlation between South African kimberlites and South Atlantic hotspots. Nature, 324, 243-245.

Mahotkin, I.L., Gibson, S.A., Thompson, R.N., Zhuravlev, D.Z., Zherdev, P.U., 2000. Late Devonian diamondiferous kimberlite and alkaline picrite (proto-kimberlite?) magmatism in the Arkhangelsk region, NW Russia. J. Petrol., 41, 201-227.

Mitchell, R.H., 1995. Kimberlites, Orangeites and Related Rocks. Plenum, New York.

Nowell, G.M., Kempton, P.D., Pearson, D.G., 1998. $\mathrm{Hf}-\mathrm{Nd}$ isotope systematics of kimberlites: relevance to terrestrial $\mathrm{Hf}-\mathrm{Nd}$ systematics. Ext. Abstr. $7^{\text {h }}$ Int. Kimberlite Conf., Cape Town, South Africa, pp. 628-630.
Nowell, G.M., Pearson, D.G., Kempton, P.D., Noble, S.R., Smith, C.B., 1999a. Origins of kimberlites: a Hf isotope perspective. Proc. $7^{\text {th }}$ Int. Kimberlite Conf., Vol. 2, Red Roof Design, Cape Town, South Africa, pp. 616-624.

Nowell, G.M., Pearson, D.G., Kempton, P.D., 1999b. Hafnium-isotopic systematics of kimberlites, lamproites and megacrysts: implications for mantle reservoirs and the composition of Bulk Silicate Earth. $9^{\text {th }}$ Annual V.M. Goldschmidt Conf. LPI Contribution No. 971. Lunar and Planetary Institute, Houston, pp. 211-212.

Nowell, G.M., Pearson, D.G., in press. Hf isotope systematics of kimberlites and their megacrysts: new constraints on their source regions. J. Petrol.

O’Brien, H.E., Tyni, M., 1999. Mineralogy and geochemistry of kimberlites and elated rocks from Finland. Proc. $7^{\text {th }}$ Int. Kimberlite Conf., Vol. 2, Red Roof Design, Cape Town, South Africa, pp. 625-636.

Pearson, D.G., Nowell, G.M., Dowall, D.P., Kjarsgaard, B.A., Kopylova, M.G., Armstrong, J.A. this volume. The relative roles of lithosphere and convecting mantle in kimberlites from the Slave province, NWT: constraints from Re-Os isotopes and olivine population studies.

Price, S.E., 1998. Primitive kimberlite magmas from Jericho, NWT, Canada: constraints on primary magma chemistry. M.Sc. Thesis, Univ. British Columbia, Vancouver, Canada.

Schmidberger, S.S., Simonetti, A., Francis, D., Gariepy, C., 2000. Probing Archean lithopshere using the Lu-Hf systematics of peridotite xenoliths from Somerset Island, Canada. Earth Planet. Sci. Lett., 197, 245-259.

Simon, N.S.C., Carlson, R.W., Davies, G.R., Nowell, G.M., Pearson, D.G. this volume. The origin of alkremites and related rocks: enrichment history of the Kaapvaal cratonic lithosphere.

Smith, C.B., 1983. Pb, Sr and Nd isotopic evidence for sources of African Cretaceous kimberlites. Nature, 304, 51-54.

Tompkins, L.A., Meyer, S.P., Han. Z., Hu, S., Armstrong, R., Taylor, W.R. 1999. Petrology and geochemistry of kimberlites from Shandong and Liaoning provinces, China. Proc. $7^{\text {th }}$ Int. Kimberlite Conf., Vol. 2, Red Roof Design, Cape Town, South Africa, pp. 872-887.

Contact: D.P. Dowall, Arthur Holmes Isotope Geology Laboratory, Department of Geological Sciences, Durham University, South Road, Durham, DH1 3LE, UK, E-mail: d.p.dowall@durham.ac.uk 